\title{
Lexico-semantic and linguo-stylistical analysis of A. Vvedensky's and D. Kharms' art texts
}

\author{
[Лексико-семантический и лингвостилистический анализ \\ художественных текстов А. Введенского и Д. Хармса]
}

\author{
Liana M. Akhmetzyanova - Gelinya Kh. Gilazetdinova
}

DOI: 10.18355/XL.2018.11.02.37

\begin{abstract}
The article is devoted to the linguistic analysis of art structures of two avant-garde writers. The general category of texts is taken as a basis - the category of absurdity often referred to as "boffinry.» Notwithstanding the traits of similarity, the ways of realization of an art discourse differ, for example, A. Vvedensky has a dominating principle of "semantic nonsense," as well as D. Kharms - "situational nonsense" when there is either a collision of meanings or collision of situations. As a result, it is possible to speak about a conscious asemantism and an art agrammatism in the texts devoted to realize, first of all, the de-constructive function of language. Thus all the elements of standard communication are involved in skillful manipulations by Vvedensky and Kharms.
\end{abstract}

Key words: semantics, art absurdity, communication violation, language experiment, function of the nomination

\section{Аннотация}

Статья посвящена лингвистическому анализу художественных структур двух писателей-авангардистов. За основу берется общая категория текстов - категория абсурда, зачастую именуемая «заумью». При несомненных чертах сходства, различаются способы реализации художественного дискурса, так, у А. Введенского доминирующим становится принцип «семантической бессмыслицы», у Д. Хармса - «ситуационный», когда происходит либо столкновение смыслов, либо столкновение ситуаций. В результате можно говорить о сознательном асемантизме и художественном аграмматизме в текстах, направленных реализовать, прежде всего, деконструктивную функцию языка. Таким способом все элементы нормативной коммуникации оказываются вовлеченными в умелые манипуляции со стороны Введенского и Хармса.

Ключевые слова: семантика, художественный абсурд, нарушение коммуникации, языковой эксперимент, функция номинации

\section{Введение}

Определяя лексико-семантическое своеобразие художественного мира А. Введенского и Д. Хармса, важно обратить внимание на отношение знаков друг к другу, на их координированность и корреляцию в речевом произведении, иначе говоря, на парадигматические и синтагматические отношения языковых компонентов, условно обозначаемые в лингвистике изобразительновыразительными средствами языка, составляющие основу лингвостилистического анализа.

Александр Введенский и Даниил Хармс были известны широкой массе читателей прежде всего благодаря детскому словотворчеству. Так называемые «взрослые» тексты писателей были опубликованы, в большинстве своем, посмертно. И Введенский, и Хармс - представители литературной группы ОБЭРИУ (объединение реального искусства, первая половина XX века),

XLinguae, Volume 11, Issue 2, April 2018, ISSN 1337-8384, eISSN 2453-711X 
состоящей из поэтов, писателей и деятелей культуры того времени. Обэриуты творили в духе авангардизма, декларировали отказ от традиционных форм поэтического искусства. Так, естественным для них было экспериментирование с рифмой и ритмом, с семантической и грамматической системой языка, стилистическим оформлением.

«Кто мы? И почему мы?.. Мы - поэты нового мироощущения и нового искусства... В своем творчестве мы расширяем и углубляем смысл предмета и слова, но никак не разрушаем его. Конкретный предмет, очищенный от литературной и обиходной шелухи, делается достоянием искусства. В поэзии столкновение словесных смыслов выражает этот предмет с точностью механики ...» (из Манифеста ОБЭРИУ).

Следует оговорить тот факт, что ОБЭРИУ состояло из пяти групп: литературной, изобразительной, театральной, кино и музыкальной. Особое положение отводилось театру, поскольку обэриуты полагали, что литературный (драматический) сюжет с постепенной установкой на изъяснение сюжетной канвы менее интересен, в сравнении со сценическим сюжетом, направленным, прежде всего, на непосредственное осознание зрителем увиденного и услышанного, когда зритель имеет право по-своему осмыслить представленное перед его глазами и заключить в сюжетную линию свою позицию. Именно Введенский и Хармс являлись создателями театра обэриутов, впоследствии преобразованного в театр абсурда, именуемый «Радикс». Именно русский театр абсурда появился на два десятилетия раньше, чем на Западе. И именно он послужил началом создания нового поэтического языка («зауми»), главным принципом которого становится абсурд.

Абсурд - категория, нарушающая условия языковой связности, особо проявляющая себя в текстах. Абсурдистская литература призвана показать реальность не с позиции того, как бывает на самом деле, как есть, но через призму той реальности, которой нет места в существующем мире. Протест против навязываемых законов жизни находит свое выражение в деструкции принципов нормальной коммуникации.

\section{Экспериментирование со словом}

Языковые эксперименты абсурдистов-обэриутов были обозначены более точными формулировками - «заумь», «заумный язык», отражающими суть идиостиля каждого представителя данной литературно-театральной группировки, не исключая, логично, самых ярких представителей - Александра Ивановича Введенского (1904 - 1941) и Даниила Ивановича Хармса (настоящая фамилия Ювачёв) (1905 - 1942).

Использование элементов зауми в произведениях Введенского и Хармса довольно разнообразно и не имеет определенной классификации. Однако можно утверждать, что в результате их употребления возникает семантическая диффузия, когда художественный текст (текст как функционально-семантико-структурное единство) служит средством усиления семантической неопределенности, намеренной размытости содержания слов.

Под семантической диффузией понимается «неопределенность содержания языковых знаков различного уровня (морфем, лексем, словосочетаний, предложений, текстов), размытый характер границ между значениями и их категориями в семантической системе языка и в языковой коммуникации» (Kiklewicz, 2007: 302). Источником возникновения семантической диффузии является речевая (языковая) неоднозначность, выступающая смысло- и формообразующим приемом интенций автора.

Частной иллюстрацией выражения неоднозначности в тексте служит поэма Введенского «Очевидец и крыса», в которой, прежде всего, стоит обратить внимание на способы именования действующих лиц:

$\mathrm{OH}$. 
Сейчас я буду говорить.

Пока он говорит, является небольшая комната. Всё рассечено. Где ты наш мир. Ни тебя нет. Ни нас нет. На тарелках сидят Пётр Иванович Иванович Иванович, курсистка, дворецкий Грудецкий, Степанов-Песков и четыреста тридцать три испанца.

Входит Лиза или Маргарита.

Одна из двух.

Что вижу я.

Здесь общество собралось адское.

Огнём и серой пахнет здесь.

И шеи у вас какие-то пороховые,

и уши, и руки, ноги, и нось

и глаза. Вы все как в столбняке.

Уже зима который час стоит,

не вылло ль здесь убийства.

Дворецкий-Грудецкий.

Маргарита или Лиза,

чаю дать вам иль часы.

Она (одна из двух).

$A x^{l}$ Грудеикий вы подлиза

ещё с иарских времён

вы Семён.

Я спрашиваю: не было ли здесь убийства.

После этого три часа играла музыка.

Разныле вальсы и хоральь.

Кириллов за это время успел жениться. Но чего-то ему недоставало.

(Vvedenskij, 1993, т.1: 176)

Общеизвестно, имя в лингвистике предстает не только как средство номинации, но воспринимается как универсальная категория, с помощью которой можно объяснить все особенности произведения. Так, имя и персонаж предстают как неделимое целое, как смысловые концепты художественного мира автора.

Введенский предлагает различные типы номинаций, например, описательные - курсистка, четыреста тридцать три испанца, или Одна из двух, Лиза или Маргарита, Она (одна из двух) и, наконец, - Маргарита или Лиза (ныне ставшая Катей). Интересна модель имени, структурно представляющая собой, возможно, соединение двусловного (личное имя + отчество, личное имя + фамилия) и трехсловного (личное имя + полное отчество + фамилия, личное имя + полуотчество + фамилия) именования: Петр Иванович Иванович Иванович. Таким образом Введенский выводит на поверхность прием нестабильности персонажа, реализуемый на всех уровнях от способа именования до возможной его гибели (деформации, замены). Различные элементы текста - от персонажа до пространственно-временной структуры - оказываются нестабильными, постоянно трансформируясь на протяжении всего произведения. Так происходит и в пьесе «Елка у Ивановых», в которой мы можем отметить любопытный факт: дети одних родителей Пузыревых обозначаются разными фамилиями (Перов, Серова, Петрова, Комаров, Острова, Пестров, Шустрова). Принцип традиционной номинации рушится, оставляя иллюзию иерархии.

1 Здесь и далее орфографические и пунктуационные неточности авторские (А. Введенского).

XLinguae, Volume 11, Issue 2, April 2018, ISSN 1337-8384, eISSN 2453-711X 
Дети: Действующие лища:

Пе т я Пе р о в-годовальй мальчик

Ни н а С е р о в а-восьмилетняя девочка

В ар я П е т р о в а-семнадиатилетняя девочка

В о лод я Ко м ар о в-двадиатипятилетний мальчик

Со н я О с тр о в а-тридчатидвухлетняя девочка

Ми ш а П е ст р о в-семидесятишестилетний мальчик

Дун я Шу с тр о в а-восьмидесятидвухлетняя девочка

Пуз и р е в а - мать

Пу з ы р ре в - отеи

Собака В ер а

Гробовщик

Горничные, повара, солдаты, учителя латинского и греческого языка.

(Vvedenskij, 1993, т. 2: 47)

Неоднозначность в именах приводит порой к деформации, изменению именуемого, как происходит, к примеру, в пьесе Хармса «Елизавета Бам»:

Иван Иванович: Если позволите, Елизавета Таракановна, я пойду лучше домой. Меня ждет жена дома. У ней ${ }^{2}$ много ребят, Елизавета Таракановна. Простите, что я так надоел Вам. Не забывайте меня. Такой уж я человек, что все меня гоняют. За что, спрашивается? Украл я, что ли? Ведь нет! Елизавета Эдуардовна, я честный человек. У меня дома жена. У жены ребят много. Ребята хорошие. Каждый в зубах по спичечной коробке держит. Вы уж простите меня. Я, Елизавета Михайловна, домой пойду.

(Kharms, 2000, т. 1: 411)

Принцип нестабильности проявляется и в следующей характеристике. Если в начале пьесы Елизавета - взрослая женщина, то потом она превращается в девочку и начинает соответственно себя вести, играя в пятнашки.

Интересное именование персонажа появляется в стихотворении «Вода и Хню»:

$$
\begin{gathered}
\text { Хню: } \\
\text { Куда, куда } \\
\text { спешишь ть, вода? }
\end{gathered}
$$

Вода:

Налево.

Там, за поворотом стоит беседка.

В беседке барышня сидит.

Её волос чёрная сетка

окутала нежное тело.

На переносииу к ней ласточка прилетела.

Вот барышня встала и вышла в сад.

Идёт уже к воротам.

Хню:

Где?

Вода:

Там, за поворотом.

Барышня Катя ступает по травам кругльми пятками.

\footnotetext{
2 Здесь и далее орфографические и пунктуационные неточности авторские (Д. Хармса).
} 
На левом глазу василёк,

а на правом

сияет лунная горка

и фятками.

Хню:

Чем?

Boda:

Это я сказала по-водяному.

Хню:

Ой, кто-то идёт к нам!

Вода:

Где?

Хню:

Там.

Boda:

Это рыбак Фомка.

Его дочь во мне утонула.

Он идёт побить меня камнем.

Давай лучше громко

говорить о недавнем.

Не подчиненное логике нормативного построения структур именования, Хню все же определяет свою принадлежность к женскому полу далее по тексту:

\section{Хню (молча): \\ Да. Это я. \\ А вот мой жених Никандр.}

(Kharms, там же)

Имя Хню встречается в ряде произведений Хармса, например, в стихотворении «Хню», в котором это имя принадлежит персонажу с женским лицом:

Хню из леса шла пешком.

Ногами месила болота и глины.

Хню питалась корешком

рога ворона малиньл.

Или Хню рвала побеги

Веселого хмеля, туземиа рощу.

Боги ехали в телеге.

Ясно чувствовалась мощь

богов, наполненных соком лиан и столетних нев.

И мысль в черепе высоком лежала, вся окаменев.

Зубами щелкая во мху,

грудь выпятив на стяги,

варили странники уху,

летали голье летяги,

подвешиваясь иными моментами на сучках вниз головой.

(Kharms, 2000, т. 1: 121)

Как видим, происходит десемантизация имен, они оторваны от своего значения, пусты: отстраняется не столько объект, сколько отстраняется и фрустрируется само действие. Хармс собственное понимание мира, свою индивидуальную концепцию абсурдности мира отразил посредством сквозной темы обезличивания человека (Akhmetzyanova, 2009: 250). Вследствие этого, люди в текстах Хармса непрестанно унижают, калечат и убивают друг друга,

XLinguae, Volume 11, Issue 2, April 2018, ISSN 1337-8384, eISSN 2453-711X 
причем с необычайной легкостью. Обратим внимание на иллюстрирующий пример:

Алексей Алексеевич подмял под себя Андрея Карловича и, набив ему морду, отпустил его.

Андрей Карлович, бледный от бешенства, кинулся на Алексея Алексеевича и ударил его по зубам.

Алексей Алексеевич, не ожидая такого быстрого нападения, повалился на пол, а Андрей Карлович сел на него верхом, вынул у себя изо рта вставную челюсть и так обработал ею Алексея Алексеевича, что Алексей Алексеевич поднялся с полу с совершенно искалеченным лицом и рваной ноздрей.

Держась руками за лицо, Алексей Алексеевич убежал.

А Андрей Карлович протер свою вставную челюсть, вставил ее себе в рот и, убедившись, что челюсть пришлась на место, осмотрелся вокруг и, не видя Алексея Алексеевича, пошел его разыскивать.

(Kharms, 2000, т.2: 315)

Можно с уверенностью утверждать, что имена, несомненно, участвуют в создании некоего образа, но это не образ персонажа, а образ, создаваемый текстом в целом. Не персонажи, не люди, а именно знаки, фигуры речи представлены в произведениях авторов-постмодернистов (Akhmetzyanova, 2009: 132). А. Кобринский, считая проблему знака и знаковости одной из основных в обэриутской поэтике, выделяет такие приемы, как «отрыв знака от означаемого и параллельное функционирование того и другого в тексте», а также «полное отождествление знака и означаемого и замена одного из них другим» (Kobrinskiy, 2013: 85, 106).

Важной особенностью текстов Введенского и Хармса в духе абсурдизма является стирание жанровых границ, жанровый синкретизм, так, некоторые драматические произведения Хармса по форме напоминают лирические стихотворения по содержанию, даже в рамках одного лирического текста можно наблюдать смешение жанров, например, в стихотворении Хармса «Олейникову» соединены жанры стихотворного послания, оды и элегии. Кроме того, Хармс также известен созданием басен в прозе («Басня», «Четвероногая ворона» и др.), ср.:

Один человек небольшого роста сказал: “Я согласен на все, только бы быть хоть капельку повыше.” Только он это сказал, как смотрит - стоит перед ним волшебница. - Чего ты хочешь? - спрашивает волшебница. А человек небольшого роста стоит и от страха ничего сказать не может. - Ну? говорит волшебница. А человек небольшого роста стоит и молчит. Волшебница исчезла. Тут человек небольшого роста начал плакать и кусать себе ногти. Сначала на руках все ногти сгрыз, а потом на ногах.

Читатель, вдумайся в эту басню, и тебе станет не по себе.

(Kharms, 2000, т. 1: 327)

Жанровый синкретизм мы встречаем у Александра Введенского, в частности, в тексте «На смерть теософки», в который вводятся элементы послания, сказки и молитвы:

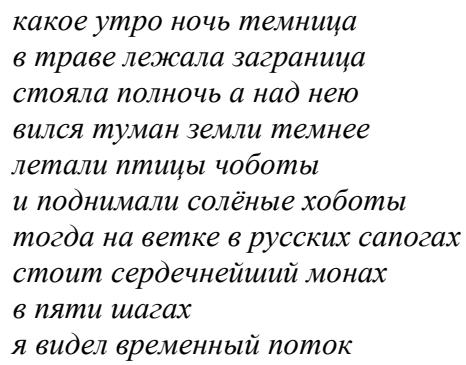


(Vvedenskij, 1993, т. 1: 66)

Само название ориентировано на жанр эпистолы, послания, в то же время автор в ходе своего повествования-размышления неоднократно проникает из реального пространства в сказочное, однако граница между мирами четко не обозначается. Обращение к Богу (молил я Бога исиели) как непосредственный элемент молитвы также находит свое отражение в тексте.

Определенно, Введенский и Хармс выходят за рамки традиционного жанрового маркирования с присущей им языковой игрой, экспериментированием над словом и смыслом.

В речевой коммуникации Введенского и Хармса обращают на себя внимание такие лингвостилистические приемы (тропы и фигуры), как метафора, сравнение, инверсия, параллелизм, различные виды повтора, тавтология, контаминация и многие другие. Остановимся на рассмотрении более частотных.

Так, излюбленными приемами Хармса становятся повтор, параллелизм, каламбур и импоссибилия.

Семантико-стилистический повтор выполняет, прежде всего, когерентную функцию, выступая в роли связующего звена в тексте, а также является ритмо-интонациональным средством выразительности. Для сравнения рассмотрим несколько текстов с некоторыми видами повтора:

- $\quad$ анафора (начальный повтор):

Профессор Трубочкин, входя:

Здравствуйте, ребята!

Здравствуйте, ребята!

Здравствуйте, ребята!

Ребята:

Здрасте, профессор!

Здрасте, профессор!

Здрасте, профессор!

Профессор:

Давно мы не встречались,

давно мы не видались,

давно не попадались

друг другу на глаза.

(Kharms, 2000, т. 3: 171)

- $\quad$ симплока (повтор в начале и конце):

Все все деревья пиф

Все все каменья пиф

Вся вся природа пур

Все все девииь пиф

Все все мужчины пиф

Вся вся женитьба пуф ...

XLinguae, Volume 11, Issue 2, April 2018, ISSN 1337-8384, eISSN 2453-711X 
- $\quad$ эпифора (конечный повтор):

Как-то вечером домой

Возвращался папа мой.

Возвращался папа мой

Поздно по полю домой.

Папа смотрит и глядит -

На земле хорёк сидит.

На земле хорёк сидит

И на папу не глядит.

(Kharms, 2000, т. 3: 296)

Рассмотренные выше композиционные виды повтора чаще всего встречаются в детских стихотворениях Хармса, в которых ярко представлена игровая функция.

Произведения для «взрослых» богаты различными типами повтора, в отдельном случае тот или иной повтор выполняет определенную функцию, и, в первую очередь, деконструктивную.

На основе лексического повтора строится синтаксический параллелизм. К примеру, параллельные синтаксические конструкции можем наблюдать в стихотворении Хармса «Вариации»:

Среди гостей, в одной рубашке

Стоял задумчиво Петров.

Молчали гости. Над камином

Железный градусник висел.

Молчали гости. Над камином

Висел охотничий рожок.

Петров стоял. Часы стучали.

Трещал в камине огонек.

И гости мрачные молчали.

Петров стоял. Трещуал камин.

Часы показывали восемь.

Железный градусник сверкал.

Среди гостей, в одной рубашке

Петров задумчиво стоял.

Молчали гости. Над камином

Рожск охотничий висел.

(Kharms, 2000, т. 2: 163)

Фонетико-морфологическая игра со словом (каламбур) наглядно представлена в следующем примере:

Это есть Это.

To есть To.

Все либо то, либо не то.

Что не то и не это, то не это и не то.

Что то и это, то и себе Само.

Что себе Само, то может быть то,

да не это, либо это, да не то.

Это ушло в то, а то уило в это.

Мы говорим: Бог дунул.

Это ушло в это, а то уило в то,

и нам неоткуда выйти и некуда прийти.

Это уило в это. Мы спросили: где?

Нам пропели: тут. 
Это выцло из Тут. Что это? Это То.

Это есть то.

То есть это.

Tут есть это и то.

Тут ушло в это, это ушло в то,

а то уило в тут.

(Kharms, 2000, т. 1: 153)

Каламбурная игра в данном случае построена на принципе свободного (созвучного) словоупотребления, создавая эффект случайного выбора.

В большинстве текстов Хармса обнаруживается такой стилистический прием, как импоссибилия (лат. impossibilis 'невозможный'), который характеризуется нагромождением в рамках одного текста неправдоподобных ситуаций:

Началось опять с небольшого

душа в зелёном венке

стала петь

тут мы слушали и вода

текла сквозь нас

мы прижались к стене

а в стену нам стали стучать

это било нас по хребту

и тонкие лампочки

тонкие лампочки

озорниць они

тонкие лампадочки

я видел над головой каждого.

Или, к примеру:

(Kharms, 2000, т. 1: 467)

Комната. Комната горит.

Дитя торчит из кольбельки.

Съедает кашу. Наверху,

под самым потолком,

заснула нянька кувырком.

Горит стена. Посуда ходит.

Бежит отеи. Отеи: "Пожар!

Вон мой мальчик, мальчик Петя,

как воздушный бьется шар.

Где найти мне обезьяну

вместо сына?" Вместо стен

печи пестрые на небо

дым пускают сквозь трубу.

Нянька сонная стрекочет.

Нянька: "Где я? Что со мной?

Мир становится короче,

Петя призраком летит".

Няня рыскает волчицей,

съест морковку на пути,

выпьет кофе. Дальше мчится,

$\kappa$ двери пробует уйти.

(Kharms, 2000, т. 1: 503)

В свою очередь, наиболее частыми приемами, к которым обращался Введенский, являются сравнение и тавтология.

XLinguae, Volume 11, Issue 2, April 2018, ISSN 1337-8384, eISSN 2453-711X 
Сравнение как яркий стилистический прием обладает способностью наделять образной характеристикой предмет, поступок или состояние человека с целью выражения авторского замысла. Сравнение в текстах Введенского следует рассматривать сквозь призму художественного абсурда или зауми. Примечательно, что в большинстве случаев происходит сравнение предметов, явлений или событий, не обладающих общим признаком для такого сравнения: прошли два года как листва («На смерть теософки»); доктор как тихая сабля («Больной который стал волной»); чудаки как пастила («Пять или шесть»); две птички как одна сова (Две птички, горе, лев и ночь); невысокий как тростник / спит на стуле воротник («Человек веселый Франц ...»); Я сидел и я пошёл / как растение на стол («Гость на коне»); солнце тихо как наука («Разговор об отсутствии поэзии») и многие другие.

Тавтология как системно-языковая аномалия в литературе Введенского рассматривается не как избыточность, но как способ концептуализации мира: тогда ребёнок молодой / молиться сочиняет («Седьмое стихотворение»); ангел певчий ангел («Галушка»); Горело всё кругом. / Спешило всё бегом, бегом; и эти молодые дети / теперь одни останутся на свете («Четыре описания»); Немного вас и мало нас («Петров в военном платье») и другие.

Анализируя разнообразие поэтических приемов Хармса и Введенского, важно отметить, что основным, объединяющим приемом остается прием словотворчества с элементами «заумного языка».

Несмотря на то, что категория абсурда являла основу творческих установок поэтов, следует отметить дифференциацию языковых аномалий.

По словам одного из членов группы ОБЭРИУ, литератора, философа, исследователя творчества Введенского и Хармса, Якова Друскина, «Произведения Введенского и Хармса объединяет «звезда бессмыслицы». Я различаю семантическую бессмыслицу, состоящую в нарушении правил обыденной, так называемой «нормальной» речи, то есть алогичность речи, и ситуационную бессмыслицу - алогичность человеческих отношений и ситуаций. У Введенского преобладает семантическая бессмыслица, у Хармса ситуационная - «борьба со смыслами» (Druskin, 2000: 399).

«Семантическая бессмыслица» Введенского возникает в результате алогического сочетания слов: «происходит чисто логическое смещение лексического значения слов в процессе их необычного взаимодействия друг с другом посредством «столкновения словесных смыслов» <..> Результатом «столкновения словесных смыслов» выступает не бессмыслица, а «видимость бессмыслицы». То есть явно подразумевается, что за внешне бессмысленным сочетанием слов присутствует некий смысл» (Shukurov, 2008: 130). С этой точки зрения «столкновение словесных смыслов» есть диссоциация, направленная, прежде всего, на семантические связи между словами, а именно, на процесс рассогласования и перераспределения их смыслового объема.

В этой связи представляется необходимым отметить, что в своем литературном поиске Введенский опирался на опыт символистов, что послужило основой для создания особого языкового знака - иероглифа. «Словам-иероглифам» (термин Л. Липавского) в поэтической системе Введенского отводится значимая роль, это сложные, неоднозначно воспринимаемые слова-знаки, со своим метафизическим (более углубленным, расширенным) значением. «Слова-иероглифы» составляют основу поэтики бессмыслицы Введенского. «Слово в поэзии Введенского выполняет функцию пустого, чистого знака. Оно не собирает в пучок семантические признаки мира, а как бы «вырезает» эти признаки из мира, оставляя на их месте зияющую прореху. Принцип ассоциативности здесь не действует: слова соединяются друг с другом не посредством ассоциации, а посредством диссоциации, то есть разложения, разобщения значений» (Feshchenko, 2004: 146). 
«Слова-иероглифы» оказываются включенными в организацию текстов писателя, помогая раскрыть главные темы: время, смерть, Бог, которые в процессе текстовой коммуникации оказываются тесно связанными между собой и рассматриваются в соотношении друг с другом.

«Слова-иероглифы» (знаки) служат авторским способом (средством) выразить то, что выходит за пределы разума и представить другую реальность. Слова теряют мотивированную связь между означаемым и означающим, тем самым устанавливая новые связи между предметами и выступая в роли «абсолютного Логоса».

Так, в «Серой тетради» Введенского (фрагментарные размышления о смерти, времени, последнем смысле слов и предметов) функционируют, например, «слова-иероглифы» яо, время, море, свобода, сон (сквозные в творчестве автора), которые, с одной стороны, воспринимаются в контексте алогично, (происходит нарушение связи на всех уровнях: дом лес и небо, как будто монголь; действие стало бессонным китаем; умерли действия, лежат мертвецами и пр.), но с другой, - позволяют выстраивать максимальное количество ассоциаций разного рода:

СВИДЕРСКИЙ.

Однажды я шел по дороге отравленный ядом, и время со мною шагало рядом.

различные птенчики пели в кустах, трава опускалась на разных местах.

могучее море как бранное поле, вдали возвышалось.

мне разумеется плохо дышалось.

Я думал о том почему лишь глаголь

подвержены часу, минуте и году.

а дом лес и небо, как будто монголь,

от времени вдруг получили свободу.

я думал и понял. Мы все это знаем.

что действие стало бессонным китаем,

что умерли действия, лежат мертвецами,

и мы их теперь украмаем венками.

Подвижность их ложь, их плотность обман,

их неживой поглощает туман.

Предметы как дети, что спят в колыбели.

Как звезды что на небе движутся еле.

Как сонные цветы, что беззвучно растут,

предметы как музыка, они стоят на месте...

(Vvedenskij, 1993, т. 1: 318)

Эти «иероглифы» обнажают состояние того, кто находится на пределе бытового мира, в переходе между жизнью и смертью, когда человек оглядывает мир вокруг и ощущает раздробленность времени, предзнаменование смерти. Мир вокруг угрожает человеку, использует его, разрушает:

Нянька стала укладывать отиа спать, превратившегося в детскую косточку. Она пела ему песню:

Над твоею кольбелью

По губам пльвёт слюна

И живет луна.

Над могилою над елью

Спи тоскуй,

Не просылайся,

XLinguae, Volume 11, Issue 2, April 2018, ISSN 1337-8384, eISSN 2453-711X 465 
Лучше рассыпайся.

Эй кузнеи куй! куй!

Мы в кузнице уснём.

Мы все узники.

И пока она пела, играла чудная, превосходная, всё и вся покоряющая музыка. И казалось, что разным чувствам есть ещё место на земле. Как чудо стоят сыновья возле тихо погасшей кровати отиа. Им хочется всё повторить. Нам страшно поглядеть в его, что называется, лицо. А подушка то порхала, то взвивалась свечкой в поднебесье, то как Днепр бежала по комнате. Потеи это холодный пот, выступающий на лбу умершего. Это роса смерти, вот что такое Потеи.

(Vvedenskij, 1993, т. 1: 254)

В связи с этим можно заметить, что означающее у Введенского настолько опустошено от предсказуемых коллокаций ${ }^{3}$, контекстов, оборотов и семантических проекций, что ему ничего не остается, как отождествиться с означаемым - предметом (Chukhrov, 2004: 83). Таким образом словесная игра позволяет вывести язык на новый уровень тексто- и смыслопорождения:

$$
\begin{gathered}
\text { увы стоял плачевный стул } \\
\text { на стуле том сидел аул } \\
\text { на нём сидел большой больной } \\
\text { сидел к живущему спиной } \\
\text { он видел речку и леса } \\
\text { где мчится стёртая лиса } \\
\text { где водит курииу червяк } \\
\text { венок звонок и краковяк } \\
<\ldots . . \\
\text { он видит здание шумит } \\
\text { и в нём собрание трещит } \\
\text { в нём создание на кафедре } \\
\text { как бы на паперти стоит } \\
\text { и руки тщетнье трясёт } \\
\text { весьма предметное растёт } \\
\text { и все смешливо озираясь } \\
\text { лепечут это мира аист } \\
\text { он одинок } \\
\text { иленист он ог } \\
\text { он сена стог } \\
\text { он бог }
\end{gathered}
$$

(Vvedenskij, 1993, т. 1: 79)

Таким образом, определяющей чертой художественной системы А. Введенского становится семантический эксперимент, в ходе которого он пытается придать словам более глубинный смысл, тем самым увеличив их семантическую емкость.

В противоположность Введенскому, определяющей чертой поэтики Хармса становится «ситуационная бессмыслица». Хармс не отделял творчество от жизни, воспринимал жизнь как величайшее чудо. В то же время он ощущал пустоту механизированной жизни, пытался посредством алогизма ситуаций

3 Коллокацией называется словосочетание, имеющее признаки синтаксически и семантически целостной единицы, в котором выбор одного из компонентов осуществляется по смыслу, а выбор второго зависит от выбора первого. 
обнажить состояние, свойственное каждому человеку в таком мире. Парадоксальное восприятие мира находит свое выражение в произведениях: Хармс сталкивает жанры, темы, ситуации, предметы и персонажи. Как следствие, деконструкции подвергаются и уровни языка: это может быть нарушение правил орфографии или пунктуации, фонетическая или лексическая заумь, морфологические или синтаксические переосмысления. В этой связи можно говорить о том, что индивидуальные черты языковой картины автора проявляются «иногда - через абсурдность описываемых ситуаций, иногда через абсурдность поведения персонажей, иногда же - через абсурдность построения текста» (Fedosyuk, 1996: 25). «Хармса привлекали нелепые, странные, иллогические ситуации, воспринимавшиеся поэтом в качестве зримого воплощения его собственной маргинальной, социальной и поэтической, позиции» (Tokarev, 2002: 25).

Показательным примером игры слов и смыслов является следующий:

Боги наги

боги маги.

Если берег начинает

волю камнями швырять

в бомбе злоба закипает

боги наги

боги маги

Вон хитреи идет на кла...

о хитрец и копуцьы...

Злая тень ему легла

вдоль щеки.

в его руке

виден штопор

o xumpeu!

Если крышу сдёрнет вдруг

Не смотри тогда наверх

Чтобы пыль и штукатурка

Не засыпали твой глаз

Боги наги

Боги маги

Лампа сама ты карзина

Не способная светить

Тёмной ванне ты кузина

Боги наги

Боги маги

Лирическое произведение буквально насыщено языковыми парадоксами. Из текста удаляются знаки препинания, создаются авторские окказионализмы (копуци), о форме и значении буквенного сочетания кла остается только догадываться, допускаются орфографические ошибки (карзина), в тексте предмет наделяется именем - саша, стирается граница между 
индивидуальным и нарицательным именами, грамматически правильно оформленные слова не складываются в грамматически нормальное предложение (Лампа саша ты карзина). Аналогичная ситуация находит свое отражение и в ряде других произведений Хармса.

В связи с эти представляется важным отметить, что произведения Хармса погружают читателя в мир абсурдных, нелепых ситуаций, главным персонажем которых, зачастую, становится Смерть. Смерть абсурдна, нелепа, комична, но, по сущности, гротескна. Смерть выводит на первый план хрупкость, иллюзорность жизни. Реальность в представлении Хармса настолько жестока и абсурдна, что должна быть равноценна смерти в своей иррациональности:

- Говорят, все хорошие бабы - толстозады. Эх, люблю грудастых баб, мне нравится, как от них пахнет, - сказав это, он стал увеличиваться в росте $u$, достигнув потолка, рассыпался на тысячу маленьких шариков. Пришёл дворник Пантелей, собрал эти царики на совок, на который он собирал обычно ломадиный навоз, и унёс эти шарики куда-то на задний двор. А солнце продолжало светить по-прежнему, $u$ пышные дамы продолжали по-прежнему восхитительно пахнуть.

(Kharms, 2000, т. 1: 479)

Тема смерти неразрывно связана с темой обезличивания человека. Люди выполняют роль знаков, это всего лишь условные единицы, готовые в одно мгновение исчезнуть, ср. рассказ Хармса «Машкин убил Кошкина»:

Товарищ Кошкин танцевал вокруг товарищза Машкина.

Товарищ Машкин следил глазами за товарищем Кошкиным.

Товарищ Кошкин оскорбительно махал руками и противно выворачивал ноги.

Товарищ Машкин нахмурился.

Товарищ Кочкин пошевелил животом и притопнул правой ногой.

Товарищ Машкин вскрикнул и кинулся на товарища Кошкина.

Товариш Кошкин попробовал убежать, но споткнулся и был настигнут товарищем Машкиным.

Товарищ Машкин ударил кулаком по голове товарищза Кошкина.

Товарищ Кошкин вскрикнул и упал на четвереньки.

Товарищ Машкин двинул товарища Кошкина ногой под живот и еще раз ударил его кулаком по затылку.

Товарищ Кошкин растянулся на полу и умер.

Машкин убил Кошкина.

(Kharms, 2000, т. 2: 228)

Идея механизированности, автоматизма бытия заставляет Хармса структурировать текст сообразно. Многочисленные текстовые примеры иллюстрируют многократную повторяемость действий персонажей, приводящую к гибели человека:

У одного старичка из носа выскочил маленький шарик и упал на землю. Старичок нагнулся, чтобы поднять этот шарик, и тут у него из глаза высккочила маленькая палочка и тоже упала на землю. Старичок испугался $и$, не зная, что делать, пошевелил губами. В это время у старичка изо рта выскочил маленький квадратик. Старичок схватил рот рукой, но тут у старичка из рукава выскочила маленькая мылика. Старичку от страха сделалось нехорошо, и он, чтобы не упасть, сел на корточки. Но тут в старичке что-то хрустнуло, и он, как мягкая плюшевая шуба, повалился на землю. Тут у старичка из прорешки выскочил длинненький прутик, и на самом конще этого прутика сидела тоненькая птичка. Старичок хотел крикнуть, но у него одна челюсть зашла за другую, и он вместо того, чтобы крикнуть, только слабо икнул и закрыл один глаз. Другой глаз у старичка остался открытым и, перестав 
двигаться и блестеть, стал неподвижным и мутным, как у мертвого человека. Так настигла коварная смерть старичка, не знавщего своего часа.

(Kharms, 2000, т. 2: 425)

\section{Заключение}

Из всего сказанного можно сделать вывод, что творческие установки Хармса и Введенского несомненно были отличны друг от друга, противопоставлялись по художественному замыслу, по акцентуации текстообразующих и смыслопораждающих моделей, в то же время, непонятная многим, но глубоко ощущаемая и интерпретируемая Хармсом и Введенским категория абсурда сближала их мировоззренческие системы, искала и находила пути к созданию новых лексико-семантических и структурно-стилистических потенциалов в текстах, тем самым при помощи «зауми» делая попытку обнажения постоянной корреляции жизни и смерти.

\section{Выражение признательности.}

Работа выполнена в соответствии с Российской правительственной Программой повышения конкурентоспособности Казанского (Приволжского) федерального университета.

\section{Bibliographic references}

KIKLEWICZ, A. 2007. Zrozumiec jezyk. Szkice z filozofii jezyka, semanytki, lngiwistyki komunikacyjnej. Lask. 374 p.

AKHMETZYANOVA, L. M. 2009. Antroponimy v khudozhestvennykh tekstakh D. Kharmsa: strukturno-semanticheskiy aspekt: dissertatsiya ... kandidata filologicheskikh nauk. Kazan. 221 p.

AKHMETZYANOVA, L.M. 2009. Istoricheskie (real'nye) imena sobstvennye v khudozhestvennom mire D. Kharmsa // Uchenye zapiski Kazanskogo gos. universiteta. Ser. Gumanit. nauki. Kazan, pp. 248-253.

GRECHKO, V. 2003. Slovotvorchestvo v poetike Kharmsa i Vvedenskogo. Elektronnyy resurs // Slavic Research Center. Hokkaido. Available online: http://srch.slav.hokudai.ac.jp/publictn/93/02gre-emb.pdf. Zagl. s ekrana.

VVEDENSKIY, A.I. 1993. Polnoe sobranie proizvedeniy v dvukh tomakh / Sost.: M. MEYLAKH, V. ERL. M.: Gileya. T. 1. 288 p. ISBN: 5-85302-013-7, 5-85302-015-3 VVEDENSKIY, A.I. 1993. Polnoe sobranie proizvedeniy v dvukh tomakh / Sost.: M. MEYLAKH, V. ERL. M.: Gileya. T. 2. 272 p. ISBN: 5-85302-013-7, 5-85302-015-3

Vlasova, L.V. 2014. Semanticheskaya diffuziya, semanticheskaya neopredelennost': opredelenie ponyatiy // Vestnik Leningradskogo gos. universiteta im. A.S. Pushkina. St.-Pb.: Leningradskiy gos. universitet im. A.S. Pushkina. T.:1, №: 2. Pp. 128-132 ISSN: 1818-6653

DRUSKIN, Ya.S. 2000. Zvezda bessmyslitsy // «Sborishche druzey, ostavlennykh sud'boyu: A. Vvedenskiy, L. Lipavskiy, Ya. Druskin, D. Kharms, N. Oleynikov: «chinari» v tekstakh, dokumentakh i issledovaniyakh: V 2-kh t. T. 1. M.: Ladomir. 846 p. ISBN 5-86218-265-9; ISBN 5-86218-268-3

KOBRINSKIY, A.A. 2013. Poetika OBERIU v kontekste russkogo literaturnogo avangarda XX veka. S.-Pb.: Svoe izd-vo. 364 p. ISBN 978-5-4386-0106-7

TOKAREV, D.V. 2002. Kurs na khudshee: absurd kak kategoriya teksta u Daniila Kharmsa i Semyuelya Bekketa. M.: Novoe literaturnoe obozrenie. 336 p. ISBN 586793-172-2

FEDOSYUK, M. 1996. Postroenie khudozhestvennogo prozaicheskogo teksta na materiale rasskazov Daniila Kharmsa // Opuscula Polonica Et Russica. № 4. Pp. 2426.

FESHCHENKO, V. V. 2004. Mnimosti v semantike (o nekotorykh osobennostyakh «chinarnogo yazyka» Aleksandra Vvedenskogo i Yakova Druskina) // Aleksandr

XLinguae, Volume 11, Issue 2, April 2018, ISSN 1337-8384, eISSN 2453-711X 
Vvedenskiy i russkiy avangard: materialy mezhdunarodnoy nauchnoy konferentsii. S.-Pb.: IPTs SPGUTD. Pp. 139-149.

KHARMS, D. 2000. Sobranie sochineniy: V 3 t. T. 1: Aviatsiya prevrashcheniy. S.Pb.: Azbuka. 576 p. ISBN 5-267-00393- Kh, 5-267-00397-2

KHARMS, D. 2000. Sobranie sochineniy: V 3 t. T. 2: Novaya anatomiya. S.-Pb.: Azbuka. 412 p. ISBN 5-267-00393-Kh

KHARMS, D. 2000. Sobranie sochineniy: V 3 t. T. 3: Tigr na ulitse. S.-Pb.: Azbuka. 384 p. ISBN 5-267-00393- Kh, 5-267-00399-9

CHUKHROV, K. 2004. Bessmyslitsa kak instrument vozvysheniya // NLO. M. № 69. Pp. $70-87$.

SHUKUROV, D. L. 2008. Ieroglificheskoe slovo v diskurse OBERIU / Jestetika: Vchera. Segodnja. Vsegda. Vyp. 3. M.: IF RAN. 248 p. ISBN 978-5-9540-0099

Words: 5169

Characters: 37112 (20,62 standard pages)

Assoc. Prof. Liana M. Akhmetzyanova, PhD. (Philology)

Institute of Philology and Intercultural Communication

Kazan (Volga region) federal university

18 Kremlyovskaya Street

420008 Kazan

Russia

lianaorx@rambler.ru

Doctor of Philology, Professor Gelinya Kh. Gilazetdinova Institute of Philology and Intercultural Communication

Kazan (Volga region) federal university

18 Kremlyovskaya Street

420008 Kazan

Russia

ggilaz@mail.ru 